\title{
HEPARIN INHIBITS PSEUDOMONAS ADHERENCE TO SOFT CONTACT LENSES
}

\author{
J. A. DURÁN ${ }^{1}$, A. MALVAR ${ }^{2}$, M $^{\mathrm{a}}$ T. RODRIGUEZ-ARES ${ }^{2}$ and C. GARCÍA-RIESTRA ${ }^{3}$ \\ Santiago de Compostela, Spain
}

\begin{abstract}
SUMMARY
Adherence of bacteria to the surface of contact lenses may play an important role in contact lens intolerance and corneal infections. To decrease the capability of bacteria to adhere to contact lenses we incubated two types of soft contact lenses with two strains of Pseudomonas aeruginosa (serotypes $0: 11$ and $0: 8$ ) at a concentration of $5 \times 10^{7}$ c.f.u./ml for 12 hours. When heparin was added to the medium at a concentration of $1000 \mathrm{IU} / \mathrm{ml}$ the numbers of bacteria adhering to the contact lenses were significantly fewer than in the controls $(\boldsymbol{p}<\mathbf{0 . 0 0 5})$. Our results suggest that heparin, either included in contact lens solutions or bonded to the surface of the contact lens, may decrease contact-lens-related morbidity.
\end{abstract}

Infectious keratitis is the most serious complication related to contact lens use. Frequently the agent responsible is Pseudomonas aeruginosa, ${ }^{1-4}$ and extended wear has been demonstrated to increase this risk. ${ }^{5,6}$

P. aeruginosa has a high capability of adhering to the surface of different types of unused contact lenses, ${ }^{7.8}$ and deposits may facilitate such adherence. ${ }^{9}$ The role of adherent bacteria in contact-lens-related pathology is unknown, but there is evidence of the presence of bacteria and biofilm in the contact lenses of patients with corneal ulcers. ${ }^{10}$

Decreasing the ability of bacteria to adhere to contact lenses may influence the incidence of contact-lens-related infection. Such a procedure would have to: (1) be safe for the eye, (2) produce no contact lens spoilage, (3) be effective for different bacteria and contact lenses, (4) induce no bacterial changes, and (5) be durable. In this study we investigated the effect of heparin on the adherence of $P$. aeruginosa to hydrogel contact lenses.

\section{MATERIALS AND METHODS}

\section{Bacteria}

Two strains of $P$. aeruginosa were isolated from a contact-

From: 'Department of Ophthalmology, Universidad del Pais Vasco; Departments of ${ }^{2}$ Ophthalmology and ${ }^{3}$ Microbiology, Universidad de Santiago de Compostela, Spain.

Correspondence to: Juan A. Durán, MD, Department of Ophthalmology, Hospital de Cruces, 48903 Vizcaya, Spain. lens-related corneal ulcer (PA1) and from a pulmonary infection (PA2). PA1 was serotype 0:11 and PA2 was serotype $0: 8$. Isolates were obtained after incubation with tryptic soy agar (TSA), and aliquots maintained at $80^{\circ} \mathrm{C}$ in tryptic soy broth (TSB) supplemented with $10 \%$ glycerol.

For each experiment bacteria were allowed to grow overnight in blood-agar at $37{ }^{\circ} \mathrm{C}$. One colony was introduced into Müller-Hinton broth with $5 \mu \mathrm{Ci} / \mathrm{ml} \mathrm{D}-\left[6{ }^{3} \mathrm{H}\right]$ glucose (Amersham, Amersham, UK) and maintained at $37{ }^{\circ} \mathrm{C}$ for 20 hours. The bacterial suspension was centrifuged three times in phosphate-buffered saline (PBS) at $9000 \mathrm{rpm}$ and the concentration adjusted to $10^{8}$ c.f.u. $/ \mathrm{ml}$ by colorimetry (Api, ATB 1550). One millilitre of the final suspension was introduced into scintillating liquid (Ready Protein + , Beckman, Fullerton, CA) in order to establish isotope uptake.

\section{Contact Lenses}

Two types of hydrogel contact lenses were used, the choice being based on surface, water content and composition characteristics: (1) Soft-Mate (Barnes Hind, Sunnyvale, CA), ionic bufilcon-A with $45 \%$ water; and (2) Hydron (Allergan Medical Optics, Irvine, CA), non-ionic polymacon with $38 \%$ water. In order to avoid variability in thickness all contact lenses ranged from +0.50 to -0.50 dioptres.

\section{Experiments}

Therapeutic sodium heparin (Leo, Madrid, Spain) was diluted in PBS to a concentration of 200 or $2000 \mathrm{IU} / \mathrm{ml}$. One millilitre of each was introduced into a plastic well (Cluster 24, Coster, Cambridge, MA) together with $1 \mathrm{ml}$ bacterial suspension and one of the contact lenses. Note that the final concentration of bacteria in this medium was $5 \times 10^{7}$ c.f.u./ml and of heparin 100 or $1000 \mathrm{IU} / \mathrm{ml}$. Wells were maintained at room temperature in an orbital stirrer for 12 hours. For each experiment one contact lens was introduced into $1 \mathrm{ml}$ bacterial suspension and $1 \mathrm{ml} \mathrm{PBS}$ as control.

Contact lenses were separated with sterile forceps, 
Table I. Soft-Mate contact lens: number of bacteria $\times 10^{3}$ per lens

\begin{tabular}{lcl}
\hline & PA1 $(0: 11)$ & \multicolumn{1}{c}{ PA2 $(0: 8)$} \\
\hline Control & $11545 \pm 5445$ & $5441 \pm 1686$ \\
Heparin 100 & $8179 \pm 5372(\mathrm{NS})$ & $4119 \pm 1039(\mathrm{NS})$ \\
Heparin 1000 & $3362 \pm 1946^{*}$ & $1246 \pm 329^{*}$ \\
\hline
\end{tabular}

*Statistically significant $(p<0.005)$; NS, not significant.

washed in a vortex with $2 \mathrm{ml}$ PBS in order to separate nonattached bacteria, introduced into vials with scintillating liquid and radioactivity counted in a beta counter (LS 3801, Beckman, Palo Alto, CA) for a minimum of 15 minutes.

Media were cultured on blood-agar for the assessment of bacterial growth and final contamination. In all cases $P$. aeruginosa grew; one experiment was rejected because of contamination with Proteus sp.

Each of the experiments included: (1) $1 \mathrm{ml}$ bacterial suspension for the radioactivity control, (2) PA1 or PA2 with heparin $100 \mathrm{mIU} / \mathrm{ml}$, (3) PA1 or PA2 with heparin $1000 \mathrm{IU} / \mathrm{ml}$ and (4) a contact lens control. All experiments were repeated at least 8 times. Results were expressed as the number of bacteria per contact lens. Statistical analysis of the results included the non-parametric Mann-Whitney test and Kruskal-Wallis test.

\section{RESULTS}

After 12 hours of incubation the numbers of $P$. aeruginosa adhering to the Soft-Mate contact lens (control) were $11545 \pm 5445 \times 10^{3}$ for PA1 and $5441 \pm 1686 \times 10^{3}$ for PA2 (Table I). In the presence of $100 \mathrm{IU} / \mathrm{ml}$ heparin the results were $8179 \pm 5372 \times 10^{3}$ and $4119 \pm 1039 \times 10^{3}$ respectively (not significant). In the presence of 1000 $\mathrm{IU} / \mathrm{ml}$ heparin the results were $3362 \pm 1946 \times 10^{3}$ and $1246 \pm 329 \times 10^{3}$ respectively, both being significantly lower compared with the controls $(p<0.005)$.

For the Hydron contact lens the numbers of bacteria (control) adhering after 12 hours were $10150 \pm 3640 \times$ $10^{3}$. for PA1 and $7174 \pm 1686 \times 10^{3}$ for PA2 (Table II). When $100 \mathrm{IU} / \mathrm{ml}$ heparin were present these numbers changed to $6552 \pm 2875 \times 10^{3}$ and $5389 \pm 882 \times 10^{3}$ respectively, statistically lower than the controls $(p<0.05)$. In the presence of $1000 \mathrm{IU} / \mathrm{ml}$ heparin the results were $2466 \pm 633 \times 10^{3}$ and $1125 \pm 263 \times 10^{3}$ (highly significant, $p<0.005$ ).

\section{DISCUSSION}

P. aeruginosa is a bacterium frequently isolated from corneal ulcers related to contact lens use, and serotype 0:11 has been reported to be the most frequent isolate. ${ }^{11,12}$ In our study adherence of this serotype was higher than that of serotype $0: 8$, being even more marked on one of the contact lens types. Moreover, Mayo et al. found that strains isolated from contact lens solutions are more likely to have a high number of plasmids. ${ }^{12}$ Several studies have shown the capability of $P$. aeruginosa to adhere to soft contact lenses ${ }^{5,6,13}$ and how adherence could be influenced by different factors such as the presence of mucin or other tear compounds. ${ }^{14-16}$ Also, $P$. aeruginosa adherent to contact
Table II. Hydron contact lens: number of bacteria $\times 10^{3}$ per lens

\begin{tabular}{lcl}
\hline & PA1 $(0: 11)$ & \multicolumn{1}{c}{ PA2 $(0: 8)$} \\
\hline Control & $10150 \pm 3640$ & $7174 \pm 1686$ \\
Heparin 100 & $6552 \pm 2875^{*}$ & $5389 \pm 882^{*}$ \\
Heparin 1000 & $2466 \pm 633^{* *}$ & $1125 \pm 263^{* *}$ \\
\hline
\end{tabular}

Statistically significant: ${ }^{*} p<0.005 ;{ }^{*} p<0.05$.

lenses can induce a bacterial keratitis under specific circumstances. $^{17,18}$

The results of our study show clearly that heparin can inhibit the numbers of $P$. aeruginosa attached to the surface of two types of soft contact lens. The anti-adherent bacterial effect of heparin was first documented by Hanno et al. in 1978 and Parsons et al. in 1979, in studies on experimental infections of the bladder. ${ }^{19,20}$ Other authors found similar results. ${ }^{21-23}$ Ruggieri et al. compared its antiadherent effect on five bacterial species; it was least effective for $P$. aeruginosa. ${ }^{22,23}$ The mechanism by which heparin inhibits bacterial attachment is not fully understood, but it is not based on its anticoagulant effect. ${ }^{24}$ Heparin is a glycosaminoglycan and when exposed to a substrate forms a molecular layer of water that prevents attachment of bacteria to the surface via adhesins. ${ }^{19}$ Thus, heparin does not seem to have an antibacterial effect.

The use of heparin for the prevention of contact-lensrelated corneal infections could be approached in two different ways: (1) by adding it to contact lens solutions or (2) by coating the contact lens with it. The first possibility comes directly from our method. From the biological characteristics of heparin no local side effects or changes in the bacteria are expected since it does not have a direct effect on the bacteria. Further, it could diminish the amount of deposits of bacterial origin with its antigenic charge $^{25,26}$ and thus reduce the risk of conjunctival inflammation. $^{27}$

The other potential approach, of incorporating a layer of heparin on the surface of the contact lens, has already been done with intraocular lenses to reduce bacterial deposits (Pharmacia, Uppsala, Sweden) and in urethral catheters to decrease the risk of infection (heparin-bonded polyurethane (HBP), Bard Co., Lombard, IL). Since contact lenses are subject to manipulation and abrasion, which could remove the heparin coating, a disposable soft heparin-coated contact lens could be useful in cases where the risk of infection is high (e.g. therapeutic lenses) or where there is a history of contact lens intolerance.

This study was supported in part by Allergan SAE.

Key words: Contact lenses, Cornea, Heparin, Keratitis, Pseudomonas.

\section{REFERENCES}

1. Galentine PG, Cohen EJ, Laibson PR, et al. Corneal ulcers associated with contact lens wear. Arch Ophthalmol 1984; 102:891-4.

2. Alfonso E, Mandelbaum S, Fox MJ, et al. Ulcerative keratitis associated with contact lens wear. Am J Ophthalmol 1986;101:429-33.

3. Ormerod LD, Smith RE. Contact lens-associated microbial keratitis. Arch Ophthalmol 1986;104:79-82. 
4. Chalupa E, Swarbrick HA, Holden BA, et al. Severe corneal infections associated with contact lens wear. Ophthalmology 1987;94:17-22.

5. Schein OD, Glynn RJ, Poggio EC, et al. The relative risk of ulcerative keratitis among users of daily-wear and extendedwear soft contact lenses. N Engl J Med 1989;321:773-8.

6. Poggio EC, Glynn RJ, Schein OD, et al. The incidence of ulcerative keratitis among users of daily-wear and extendedwear soft contact lenses. N Engl J Med 1989;321:779-83.

7. Dart JK, Badenoch PR. Bacterial adherence to contact lenses. CLAO J 1986;12:220-4.

8. Durán JA, Refojo MF, Gipson IK, et al. Pseudomonas attachment to new hydrogel contact lenses. Arch Ophthalmol 1987;105:106-9.

9. Aswad MI, John T, Barza M, et al. Bacterial adherence to extended-wear soft contact lenses. Ophthalmology 1990;97: 296-302.

10. Holland S, Ruseka I, Alfonso E, et al. Biofilm, Pseudomonas and extended wear contact lens. Invest Ophthalmol Vis Sci 1988; (ARVO Suppl) 29:249.

11. Wilson LA, Schlitzer RL, Ahearn DG. Pseudomonas corneal ulcers associated with soft contact lenses wear. Am J Ophthalmol 1981;92:546-54.

12. Mayo MS, Cook WL, Schlitzer RL, et al. Antibiograms, serotypes and plasmid profiles of Pseudomonas aeruginosa associated with corneal ulcers and contact lens wear. J Clin Microbiol 1986;24:372-6.

13. Stern GA, Zam ZS. The pathogenesis of contact lens-associated Pseudomonas aeruginosa corneal ulceration. I. The effect of contact lens coatings on adherence of Pseudomonas aeruginosa to soft contact lenses. Cornea 1986;5: 41-5.

14. Butrus SI, Klotz SA, Misra RP. The adherence of Pseudomonas aeruginosa to soft contact lenses. Ophthalmology 1987;94:1310-4.

15. Miller MJ, Wilson LA, Ahearn DG. Effects of protein, mucin and human tears on adherence of Pseudomonas aeruginosa to hydrophilic contact lenses. J Clin Microbiol 1988; 26:513-7.
16. Klotz SA, Butrus SI, Misra RP, et al. The contribution of bacterial surface hydrophobicity to the process of adherence of Pseudomonas aeruginosa to hydrophilic contact lenses. Curr Eye Res 1989;8:195-202.

17. Durán JA, Refojo MF, Kenyon KR. Hydrogel contact lensinduced Pseudomonas keratitis in a rabbit model. Cornea $1987 ; 6: 258-60$

18. Aswad MI, Barza M, Baum J. Effect of lid closure on contact lens-associated Pseudomonas keratitis. Arch Ophthalmol 1989; 107:1667-70.

19. Hanno PM, Parsons CL, Shrom SH, et al. The protective effect of intravesical heparin in experimental bladder infection. J Surg Res 1978;25:324-9.

20. Parsons CL, Mulholland SG, Anwar H. Antibacterial activity of bladder surface mucin duplicated by exogenous glycosaminoglycan (heparin). Infect Inmun 1979;24:552-7.

21. Chin JL, Sharpe JR. The anti-adherence effect of heparin: a visual analysis. Urol Res 1983;11:173-9.

22. Ruggieri MR, Hanno PM, Levin RM. The effects of heparin on the adherence of five species of urinary tract pathogens to urinary bladder mucosa. Urol Res 1984;12:199-203.

23. Ruggieri MR, Hanno PM, Levin RM. Further characterisation of bacterial adherence to urinary bladder mucosa: comparison with adherence to anion exchange resin. J Urol 1985; 134: 1019-23.

24. Hanno PM, Fritz RW, Mulholland SG, et al. Heparin, an examination of its antibacterial adsorption properties. Eur Urol 1981;7:359-62.

25. Fowler SA, Allansmith MR. Evaluation of soft contact lens coatings. Arch Ophthalmol 1980;98:95-9.

26. Liotet S, Guillaumin D, Coechet $\mathrm{P}$, et al. The genesis of organic deposits on soft contact lenses. CLAO J 1983;9: $49-56$.

27. Baleriola-Lucas C, Grant T, Newton-Howes J, et al. Enumeration and identification of bacteria on hydrogel lenses from asymptomatic patients and those experiencing adverse responses with extended wear. Invest Ophthalmol Vis Sci 1991; (ARVO Suppl) 32:739. 